\title{
PENGARUH KUALITAS PELAYANAN TERHADAP KEPUASAN NASABAH DAN LOYALITAS NASABAH BANK PAPUA KANTOR CABANG PEMBANTU WAENA DIMASA PANDEMI COVID-19
}

\author{
Ezra Aruman \\ ezra.aruman@gmail.com
}

Fakultas Ekonomi dan Bisnis Universitas Cenderawasih

\begin{abstract}
Abstraksi:
Penelitian ini untuk menganalisis dan memperoleh bukti empiris pengaruh kualitas layanan terhadap kepuasan nasabah, dan loyalitas nasabah. Metode penelitian yang di gunakan dalam penelitian adalah Deskriptif kuantitatif di laksanakan pada bulan Juni 2021.Populasi sebanyak 60 orang.Sampel sebanyak 60 orang. Data primer dan sekunder kemudian dianalisis menggunakan teknik analisa deskriptif berbentuk analisa statistik dengan bantuan aplikasi SPSS. Hasil penelitian ini dikumpulkan melalui kuesioner yang diproses dan dianalisis dengan menggunakan Regresi Berganda dan melakukan uji kualitas data yang digunakan adalah uji validitas dengan menggunakan Corrected Item Total dan uji reabilitas menggunakan Cronbach Alpha. Untuk uji hipotesis dalam penelitian ini. Peneliti menggunakan uji t, dan uji $\mathrm{F}$ serta melakukan uji determinasi. Hasil penelitian ini menunjukkan bahwa terdapat pengaruh positif variabel Kualitas Pelayanan $(X)$, terhadap variabel Kepuasan Nasabah $(Y)$. Dengan demikian secara parsial ada pengaruh yang signifikan antara kualitas pelayanan terhadap kepuasan nasabah. Terdapat pengaruh positif variabel kualitas pelayanan $(X)$ terhadap variabel loyalitas nasabah (Z) sehingga dengan demikian secara parsial ada pengaruh yang signifikan antara kualitas pelayanan terhadap loyalitas nasabah. Terdapat pengaruh positif variabel kepuasan nasabah $(Y)$ terhadap variabel loyalitas nasabah (Z) sehingga dengan demikian secara parsial ada pengaruh yang signifikan antara kepuasan nasabah terhadap loyalitas nasabah dan ditambah adanya kepuasan nasabah. Terdapat pengaruh langsung antara kualitas pelayanan terhadap loyalitas melalui kepuasan nasabah pada Bank Papua KCP Waena.
\end{abstract}

Kata Kunci : Kualitas pelayanan, Kepuasan Nasabah dan Loyalitas Nasabah

\section{PENDAHULUAN}

\section{A. Latar Belakang}

Bank adalah salah satu lembaga yang penting untuk diperhatikan dalam kegiatan perbankan. Dalam perbankan kegiatannya adalah memberikan pelayanan kepada nasabah untuk memenuhi kebutuhan masyarakat. Bank juga merupakan badan usaha menghimpun dana dari masyarakat dalam bentuk simpanan dana menyalurkan kepada masyarakat dalam bentuk kredit dan bentuklainnya di mana rangka meningkatkan taraf hidup rakyat. Setiap perusahaan di tuntut untuk membuat pelanggan merasa puas dengan memberikan penawaran dan pelayanan yang baik kelangsungan hidup suatu perusahaan tergantung pada kepuasan pelanggannya.

Kualitas pelayanan adalah suatu tingkatan pengukuran nasabah mengenai produk, jasa dan lingkungan yang memenuhui bahkan melampaui harapan nasabah. Keunggulan suatu jasa perbankan sangat tergantung dari kualitas pelayanan yang diperhatikan, apakah sudah sesuai dengan harapan dan keinginan pelanggan atau belum sesuai dengan nasabah. Ada beberapa faktor yang harus di perhatikan oleh perusahaan berkaitan dengan kualitas pelayanan, antara lain bukti fisik (tangibles) (reliability), daya tangap (responsivensss), Jaminan (assurance), dan empati (empathy).

Ketika seorang nasabah mendapatkan pelayanan yang baik dari sebuah Bank Papua maka semakin baik pula tingkat kepercayaan yang di miliki oleh nasabah terhadap hubungan baik dengan Bank. Bank Papua Kantor Cabang pembantu waena adalah salah satu Bank yang bergerak dalam pelayanan terhadap nasabah untuk memenuhi kebutuhan masyarkat dan bersaingan dalam perbankan seperti Bank Papua lain yang berkualitas pelayanan terhadap kepuasan nasabah. Di tengah persaingan yang seperti inilah kualitas pelayan yang baik terhadap konsumen sangat dibutuhkan oleh pihak Bank Papua. Oleh karena itu manajeman harus dapat memberikan pelayanan yang baik bagi nasabah, sehingga nasabah dapat merasa puas dengan apa yang mereka dapatkan di Bank Papua kantor Cabang pembantu Waena.

Keunggulan suatu jasa perbankan sangat tergantung dari kualitas pelayanan terhadap nasabah apakah sudah sesuai dengan harapan atau keinginan nasabah Bank.Nasabah sebagai salah satu sumber utama perusahaan perbankan untuk memberikan pelayanan dan kinerja yang baik agar nasabah merasa puas. Nasabah selalu mengharapakan agar pelayanan 
dibidang jasa perbankan dapat memberikan pelayanan yang baik dan memuaskan seperti fasilitas yang baik, keramahan, serta ketanggapan dan kemampuan, dengan demikian pihak Bank dituntut untuk selalu berusaha meningkatkan pelayanan nasabah. Bagi nasabah kualitas layanan yang diberikan dari Bank kepada pelanggan sehingga perusahaan dapat mengevaluasi kualitas Pelayanan nasabah yang bermutu menuntut adanya upaya keseluruhan layanan terhadap nasabah bank bukan hanya tugas di From office yang berhadapan langsung dengan nasabah dalam menghasilkan pelayanan yang mencerminkan kualitas, tetapi juga karyawan di back office.

Akibat dari Pandemi Covid-19 ini, Bank Papua Kantor Cabang Pemebantu Waena menghadapi isu-isu yang akan berdanpak pada perbankan. Ada beberapa perubahan yang terjadi pada perbankan yaitu;Tutup beberapa Kantor-kantor kas, kantor cabang pemabantu dan layanan Bank di pindahkan ke kantor Cabang, hal ini dilakukan untuk menghindari risiko kepuasahan nasabah Bank Papua Kantor Cabang Pembantu Waena dalam mengantisipasi isu krisis akibat pandemi Covid19 maka banyak yang akan nenanggung rsiko yang akan terjadi, karena pada proses berjalan sistem dan juga perkembang, termasuk kepuasan nasabah Bank Papua kantor Cabang pembantuh Waena beberapa kepuasan nasabah yang akan timbul dari faktor termasuk kualitas pelayanan terhadap kepuasan nasabah pada saat pandemic Covid-19. Kualitas pelayanan sebagai faktor internal Bank Papua maupun dari kepuasahan nasabah faktor eksternal. Bank Papua kantor Cabang Waena seperti biasa melakukan pekerjaan dan mengikuti protokol kesehatan yaitu mencuci tangan, memakai masker dan menjaga jarak untuk mencegah Virus Corona atau Pandemi Covid-19. Pada kasus tersubut akan timbul risiko kualitas pelayanan terhadap kepuasan nasabah pada Bank Papua Kantor Cabang Pembantu Waena.

Perbedaan kualitas pelayanan tehadap kepuasan nasabah pada Bank Papua KCP Waena sebelum dan dimasa pandemi covid-19. Sebelum pandemi covid-19 pelayanan terhadap nasabah adalah tepati waktu dalam pelayanan, masuk kantor sesuai jadwal dan jam yang sudah tentukan, tidak membatasi jumlah nasabah yang masuk dalam ruang,memenuhi dan kebutuhan nasabah, sepertinya memberikan kredit kepada nasabah, membuka buku tabungan,nasabah berintersaksi langsung, dan bercaba tangan antara karyawan dan nasabah lainnya yang ada di ruangan dan saat antrian, berinteraksi antara satu sama yang lain, serta muda untuk penangganan dalam keluhan nasabah dan meningkatkan pelayanan. Sedangkan dimasa pandemi covid-19 kualitas pelayanan terhadap kepuasan nasabah adalah membatasi aktifitas di kantor-kantor terlebih khususnya adalah bidang perbankan. Bank sebagian besar kerja dari rumah dan sebagian kerja di kantor dengan jumlah yang terbatas $5 \%$ untuk memenuhui kebutuhan masyarakat dimasa pandemi covid-19. Dan dibatasai dengan kontak langsung, jaga jarak,ruangan yang nyaman, jam kerja dari jam 6:00 - 4:00, dan nasabah yang tidak merasa puas karena nasabah harus menerapkan protokol kesehatan dalam ruangan dan dimana nasabah berada, agar perbankan tetap menjaga eksistensinya di tengah pandemi covid-19. Oleh karena itu menjadi penting bagi perbankan termasuk Bank Papua KCP Waena dalam meningkatkan kualitas pelayanannnya, terlebih pada produk yang saat ini banyak digunakan oleh nasabah.

\section{B. Tujuan Penelitian}

Berdasarkan latar belakang yang dikemukakan di atas, maka tujuan yang hendak dicapai melalui penelitian ini adalah sebagai berikut:

a) Untuk mengetahui pengaruh kualitas pelayanan terhadap kepuasan nasabah pada Bank Papua KCP Waena dimasa Pandemi Covid-19.

b) Untuk mengetahui pengaruh kualitas pelayanan terhadap loyalitas nasabah pada Baank Papua KCP Waena dimasa pandemi Covid-19.

c) Untuk mengetahui pengaruh kepuasan nasabah terhadap loyalitas nasabah pada Bank KCP Waena Dimasa Pandemi Covid-19.

d) Untuk mengetahui kualitas pelayanan terhadap loyalitas nasabah melalui kepuasan nasabah pada Bank Papua KCP Waena di masa pandemi Covid-19.

\section{LANDASAN TEORI}

A. Kualitas Pelayanan

1. Definisi Kualitas Dan Pelayanan Pengaruh 
Kata kualitas memiliki banyak definisi yang berbeda. Salah satunya yaitu, kualitas merupakan suatu kondisi dinamis yang berhubungan dengan produk, jasa, manusia, proses, dan lingkungan yang memennuhui atau melebihi harapan. Definisi lain juga menjelaskan kualitas sebagai suatu strategi dasar bisnis yang menghasilkan barang dan jasa yang memenuhui kebutuhan dan kepuasan konsumen internal dan eksternal, secara eksplisit dan implisit.

Kualitas pelayanan merupakan tindakan seseorang kepada pihak lain melalui panyajian produk atau jasa sesuai dengan selera, harapan dan kebutuhan konsumen. Jika perusahaan dapat memberikan pelayanan sesuai dengan keinginan dan harapan konsumen maka kualitas pelayanan perusahaan tersebut baik. Pelayanan yang baik tersebut akan memberikan dorongan kepada komsumen untuk melakukan pembelian ulang di perusahaan tersebut.

\section{Faktor-faktor yang Mempengaruhi Kualitas Pelayanan}

Menurut Tjiptono, (2014:70) 5 faktor yang menetukan kualitas pelayanan jasa yang digunakan sebagai analisis pada perusahaan jasa. Kelima faktor tersebut meliputi sebagai berikut:

a) Bukti langsung (Tangibles), meliputi fasilitas fisik, perlengkapan, pegawai dan sarana komunikasi seperti peralatan medis dengan teknoligi terbaru, kebersihan tempat tidur nasabah, keindahan tata letak tempat tidur kenyamanan ruangan dan suasana tenanag (tidak berisik).

b) Keadaan (Reliability), yakni kemampuan memberikan pelayanan yang dijanjikan dengan segera, akurat dan memuaskan seperti prosedur administrasi yang mudah, kecepatan pelayanan nasabah, respon yang cepat terhadap kebutuhan nasabah dan karyawan bekerja sesuai dengan ketentuan.

c) Daya tanggap (Responsiveness), yaitu keinginan pada staf untuk membantu para pelanggan dan memberikan pelayanan dengan tanggap seperti pelayanan informasi yang memadai, kecepatan teller melayani nasabah, kecepatan staf dalam proses administrasi dan perhatian petugas terhadap ruang.

d) Jaminan (assurance), mencakup pengetahuan, kemampuan, kesopanan, dan staf;bebasdari bahaya resiko atau keragu-raguan seperti kenyamanannasabah, bunga yang bersaing, pengetahuan karyawan dalam tindakan tertentu, sikap sopan nasabh dan keamanan dan kejujuran dalam transaksi.

e) Empati (Emphaty), meliputi kemudahan dalam melakukan hubungan komunikasi yang baik, perhatikan pribadi dan memahami kebutuhan para pelanggan, seprti pelayanan teller tanpa memandang status nasabah, kejelasan petnujuk teller untuk bertanya, kesabaran petugas dalam menangani keluhan nasabah, perhatikan yang tulus dalam membantu dan konsultasi nasabah dan penyelesaiannya.

\section{Pengaruh Profitabilitas Terhadap Nilai Perusahaan Dengan Kebijakan Dividen Sebagai Variabel Intervening}

Ada beberapa karakteristik yang dimiliki oleh kualitas pelayanan Menurut Zemke dalam Deminus Asemki (2019), yaitu :

a) Konsumen memiliki kenangan atau memori atas pengalaman menerima pelayanan, yang tidak bisa dijual atau diberikan kepada orang lain.

b) Tujuan penyelenggaraan pelayanan adalah keunikan, setiap pelanggaran dan setiap kontak adalah diangkap sesuatu yang spesial.

c) Suatu pelayanan terjadi pada saat tertentu, ini tidak dapat disimpan digudang atau dikirimkan barang contohnya.

d) Konsumen melakukan kontrol kualitas dengan cara membandingankan harapan dan pengalaman yang diperolehnya.

e) Jika terjadi kesalahan, satu-satunya cara yang bisa dilakukan oleh karyawan untuk memperbaiki adalah meminta maaf.

f) Moral karyawan sangat menentukan untuk kelancaran pemberian pelayanan.

\section{B. Kepuasaan Nasabah}

\section{Definisi Kualitas Dan Pelayanan Pengaruh}

Kepuasan Nasabah adalah tingkat perasaan konsumen setelah membandingkan antara apa yang dia terima dan harapannya. Kepuasan nasabah merupakan pengukuran atau indikator sejauh mana nasabah atau pengguna produk perusahaan atau jasa sangat senang dengan produk-produk atau jasa yang di terima. Seorang pelanggan, jika merasa puas dengan nilai yang di berikan oleh produk atau jasa, sangat besar kemungkinannnya menjadi pelanggan dalam waktu yang lama. Tujuan dari suatu perusahaan tersebut, terutama perusahaan jasa adalah untuk menciptakan kepuasan nasabah. 
Indikator yang dapat di ukur dari kepuasan nasabah adalah sebagai berikut :

a) Kesesuaian harapan

b) Minat berkunjung kembali

c) Kesediaan merekomendasikan

\section{Konsep Kepuasan Pelanggan}

Menurut Richard L. Oliver, (2015) mendefinisikan Kepuasan pelanggan adalah tingkat perasaan seseorang setelah membandingkan kinerja atau hasil yang di rasakan dengan harapannya. Kepuasan pelanggan yaitu tingkat perasaan dimana seseorang menyatakan hasil perbandingan atas kinerja produk atau jasa yang di terima sesuai yang di harapkan. Kepuasan adalah perasaan senang atau kecewa seseorang yang muncul setelah membandingkan antara kinerja (hasil) suatu produk yang di pikirkan terhadap kinerja atau hasil yang di harapkan (Kotler, 2012 :70). Kepuasan pada dasarnya sangat sulit untuk di ukur karena kepuasana merupakan konsep yang sangat luas, kompleks dan mendalam, sehingga kepuasan antara orang akan sangat berbeda (Lucia \& Maroco (2013).

\section{Kepuasaan Nasabah}

\section{Definisi Kualitas Dan Pelayanan Pengaruh}

Dalam Penelitian ini, penulis melakukan mengukur kualitas pelayanan terhadap kepuasaan nasabah dan loyalitas nasabah pada Bank Papua KCP Waena dimasa pandemi covid-19.Studi yang dilakukan oleh Lee (2009) menemukan bahwa kepuasan nasabah mempunyai hubungan positif yang kuat dengan kepuasan nasabah. Kualitas pelayanan merupakan faktor utama atau mempunyai pengaruh yang paling kuat terhadap Kepuasan Nasabah Lee, (2009). Bank Papua KCP Waena perlu memonitor dan meningkatkan kepuasan nasabahnya karena makin tinggi kualtias pelayanan, berarti makin besar pula kemungkinan kepuasan nasabah (Kartajaya, 2006).

Sabir (2014:94) menemukan bahwa terdapat hubungan positif anatara kualitas pelayanan terhadap dan loyalitas nasabah melalui kepuasan nasabah. Salah satu alasan pelanggan berpindah brand adalah ketidak puasan. Mereka merasakan alternatif hanya membuat lebih buruk tidak seperti brand yang mereka gunakan. Hal ini didukung oleh penelitian Siddiqi (2011) dan Osman dan Sentosa (2013) yang menemukan bahwa terdapat korelasi positif antara kepuasan pelanggan dan loyalitas pelanggan sehingga manajer harus memberikan perhatian lebih untuk meningkatkan kepuasan pelanggan.

Berdasarkan dari uraian dan teori di atas tersebut, maka dapat ditarik kesimpulan bahwa kualitas pelayanan berpengaruh terhadap loyalitas nasabah melalui kepuasan nasabah.

\section{Pengaruh Kualitas Pelayanan terhadap Loyalitas Nasabah}

Sabir (2014:94) menemukan bahwa terdapat hubungan positif anatara kualitas pelayanan terhadap dan loyalitas nasabah melalui kepuasan nasabah. Salah satu alasan pelanggan berpindah brand adalah ketidak puasan. Mereka merasakan alternatif hanya membuat lebih buruk tidak seperti brand yang mereka gunakan. Hal ini didukung oleh penelitian Siddiqi (2011) dan Osman dan Sentosa (2013) yang menemukan bahwa terdapat korelasi positif antara kepuasan pelanggan dan loyalitas pelanggan sehingga manajer harus memberikan perhatian lebih untuk meningkatkan kepuasan pelanggan.Berdasarkan dari uraian dan teori di atas tersebut, maka dapat ditarik kesimpulan bahwa kualitas pelayanan berpengaruh terhadap loyalitas nasabah melalui kepuasan nasabah.

\section{Pengaruh Kepuasan Nasabah Terhadap Loyalitas Nasabah}

Kepuasan nasabah berpengaruh positif pada loyalitas nasabah. Hal ini mengindikasikan bahwa peningkatan kepuasan nasabah mengakibatkan meningkatnya loyalitas nasabah atau dengan kata lain semakin tinggi kepuasan 
nasabah maka loyalitas nasabah juga semakin tinggi. Penelitian yang dilakukan oleh Indah Dian Utaminingsih (2010) mengemukakan bahwa kepuasan nasabah berpengaruh terhadap loyalitasnya. Dengan demikian dapat dikatakan bahwa apabila keadaan menunjukkan nasabah mempunyai tingkat kepuasan yang tinggi maka loyalitasnya juga akan tinggi pula. Demikian juga sebaliknya, jika nasabah mempunyai tingkat kepuasan yang rendah, maka loyalitasnya juga akan rendah pula. Berdasarkan dari uraian dan teori di atas tersebut, maka dapat ditarik kesimpulan bahwa kepuasan nasabah berpengaruh terhadap loyalitas nasabah.

\section{Pengaruh Kualitas Layanan Terhadap Loyalitas Melalui Kepuasan Nasabah}

Kualitas pelayanan berpengaruh positif dan signifikan kepuasan konsumen. Hal ini menunjukan bahwa kualitas pelayanan yang baik akan tinggi kepuasan konsumen atas produk/jasa tersebut. Kualitas pelayanan juga berpengaruh positif dan signifikan terhadap loyalitas nasabah. Hal ini menunjukan bahwa semakin baik kualitas pelayanan maka dapat mendorong nasabah untuk merasa loyal terhadap produk/jasa tersebut. Variabel kepuasan nasabah berpengaruh positif dan signifikan terhadap loyalitas nasabah sehingga dapat disimpulkan bahwa apabila nasabah tersebut mendapat kepuasan dari Bank maka akan menciptakan loyalitas.

\section{Gambar 1. Kerangka Konseptual}

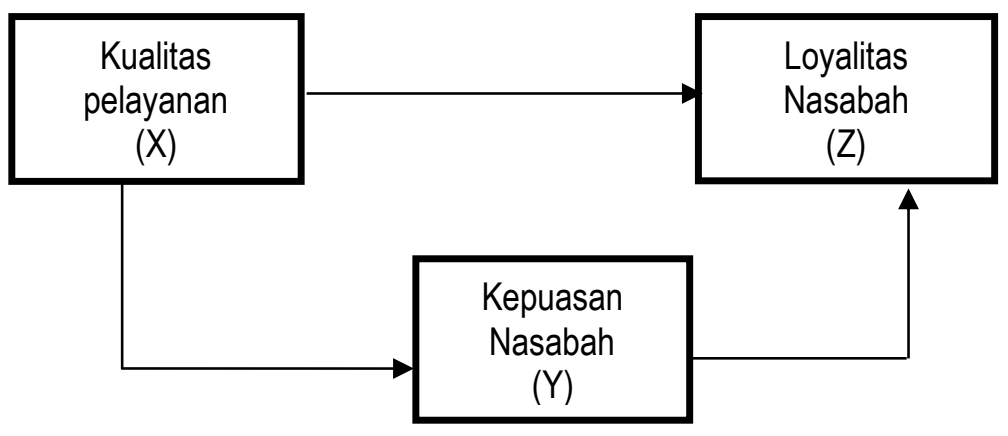

Sumber : Data diolah Tahun 2021

\section{Hipotesis}

Dari penjelasan penelitian ini ada pengaruhi kualitas pelayanan terhadap kepuasaan nasabah dan lotalitas nasabah pada Bank Papua KCP Waena dimasa Pandemi Covid-19. Berdasarkan permasalahan yang diteliti, maka penulis menarik suatu hipotesis sebagai berikut:

[H.1]. Kualitas pelayanan $(X)$ berpengaruh signifikan terhadap kepuasan nasabah (Y) pada. Bank Papua KCP Waena di masa pandemi covid-19.

[H.2]. Kualitas pelayanan $(X)$ berpengaruh signifikan terhadap loyalitas nasabah (Z) pada Bank Papua KCP Waena di masa Pandemi Covid-19.

[H.3]. Kepuasan nasabah ( $Y$ ) berpengaruh signifikan terhadap loyalitas nasabah (Z) pada Bank Papua KCP Waena di masa pandemi Covid-19.

[H.4]. Kualitas pelayanan $(\mathrm{X})$ berpengaruh signifikan terhadap loyalitas nasabah (Z) melalui kepuasan nasabah (Y). Pada Bank Papua KCP Waena di masa pandemi Covid-19.

\section{METODE PENELITIAN}

\section{A. Obyek Penelitian}


Penelitian ini meneliti tentang kualitas pelayanan terhadap kepuasaan nasabah pada Bank Papua Kantor Cabang pembantu Waena masa pandemi covid-19. Peneliti mengunakan metotde deskriptif untuk mengambarkan terhadap berbagai karakteristik variabel penelitian serta keterkaitan dengan fenomena di lapanagan mengenai pengaruh kualitas pelayanan terhadap kepuasan nasabah dan loyalitas nasabah. Lokasi penelitian merupakan tempat dimana peneliti akan memperoleh data yang berasal dari responden yang penulis teliti. Lokasi penelitian ini mengambil tempat/lokasi pada PT. Bank Papua KCP Waena.

\section{B. Populasi dan Sampel}

Populasi adalah wilayah generalisasi yang terdiri atas : obyek atau subyek yang mempunyai kualitas dan karakteristik tertentu yang ditetapkan oleh peneliti untuk dipelajari dan kemudian ditarik kesimpulannya (Sugiyono), 2012. Populasi dalam penelitian ini adalah seluruh nasabah Bank papua KCP Waena sebanyak 60 nasabah.

Sampel adalah bagian dari penelitian yang dilakukan dengan mengambil populasi yang karakteristiknya hendak diselidiki dan dianggap bisa mewakili seluruh populasi (Sugiyono, 2012). Teknik pengambilan sampel yang digunakan adalah convenience simple random sampling yaitu pengambilan anggota sampel dari populasi yang dilakukan secara acak tanpa memperhatikan strata yang ada dalam populasi tersebut (Sugiyono, 2012).

Dalam penelitian ini, maka jumlah sampel yang akan diteliti mengikuti rumus di bawah ini (Djarwanto dan Subagyo 1993)

Jika jumlah populasi tidak di ketahui, maka jumlah sampel minimal di tentukan dengan rumus yaitu :

$\mathrm{n}=\frac{1}{4} \frac{\left(\mathrm{z} \frac{1}{2} \mathrm{a}\right)^{2}}{\mathrm{E}}$

Dimana

n : Jumlah sampel

$Z \frac{1}{2}$ a : Batas luar daerah. Nilai $Z \frac{1}{2}$ a adalah sebesar 0,05 . Angka ini didapat dari tabel $t$, karena pada kondisi dimana nilai deviasi standar rata-rata tidak diketahui. Maka tabel-tabel tidak berdistribusi normal langsung sehingga untuk jumlah populasi yang tidak terbatas atau yang berjumlah besar akan mengikuti nilai tabel $Z$.

E : Kesalahan maksimum yang mungkin dialami

Dengan taraf signifikansi (a) sebesar 5\% dan kesalahan maksimum yang mungkin dialami (E) adalah sebesar $10 \%$ sedangkan deviasi standar rata-ratanya tidak diketahui, maka besarnya sampel dalam penelitian ini adalah sebanyak 60 nasabah.

\section{HASIL DAN PEMBAHASAN}

\section{A. Pengujian Instrumen Data}

Pengujian ini menggunakan bantuan komputer program SPSS versi 22. Untuk mengetahui valititas dan reliabilitas data yang di peroleh dari tiap pertanyaan responden, perlu diadakan uji pedahuluan terhadap kuesioner yang diberikan kepada responden, kemudian dari skor (data) yang diperoleh dilakukan uji validitas dan realibilitas. Pengujian terhadap validitas dan realibilitas dalam penelitian SPSS.

\section{Uji Validitas}

Dalam penelitian ini uji validitas di pergunakan untuk mengukur apakah kuesioner sebagai alat ukur yang digunakan sudah sesuai atau benar.Teknik yang digunakan adalah memakai Pearson Correlation, dihitung menggunakan bantuan komputer program SPSS. Dengan nilai r tabel 0,2564. Adapun hasil uji validitas kuesioner dari 60 responden. Hasil uji validitas dapat ditunjukkan pada tabel berikut. 
Tabel 1. Hasil_Uji Validitas Kualitas pelayanan

\begin{tabular}{|c|c|c|c|c|}
\hline Variabel & $\begin{array}{c}\text { Label } \\
\text { Pernyataan }\end{array}$ & $r$-hitung & $r$-tabel & ket \\
\hline & 1 & 0.637 & 0,2564 & Valid \\
\hline & 2 & 0.615 & 0,2564 & Valid \\
\hline & 3 & 0.290 & 0,2564 & Valid \\
\hline & 4 & 0.649 & 0,2564 & Valid \\
\hline & 5 & 0.520 & 0,2564 & Valid \\
\hline & 6 & 0.402 & 0,2564 & Valid \\
\hline & 7 & 0.530 & 0,2564 & Valid \\
\hline & 8 & 0.538 & 0,2564 & Valid \\
\hline & 9 & 0.312 & 0,2564 & Valid \\
\hline & 10 & 0.326 & 0,2564 & Valid \\
\hline & 11 & 0.156 & 0,2564 & Tidak Valid \\
\hline & 12 & 0.391 & 0,2564 & Valid \\
\hline & 13 & 0.518 & 0,2564 & Valid \\
\hline & 14 & 0.299 & 0,2564 & Valid \\
\hline & 15 & 0.313 & 0,2564 & Valid \\
\hline & 16 & 0.605 & 0,2564 & Valid \\
\hline & 17 & 0.579 & 0,2564 & Valid \\
\hline & 18 & -.183 & 0,2564 & Tidak Valid \\
\hline & 19 & 0.541 & 0,2564 & Valid \\
\hline & 20 & 0.393 & 0,2564 & Valid \\
\hline & 21 & 0.546 & 0,2564 & Valid \\
\hline & 22 & 0.019 & 0,2564 & Tidak Valid \\
\hline
\end{tabular}

Sumber : Data di olah 2021

Berdasarkan tabel di atas, dari 22 butir pertanyaan terdapat 3 butir soal yang tidak valid. Hal ini dapat dilihat dari nilai rhitung $<0,2564$. Sehingga diperoleh 19 butir pernyataan yang valid. Dan yang tidak valid dari variabel $(X)$ adalah 3 butir pertanyaan sedangkan yang valid 19 butir pertanyaan didapat dari hasil pengujian SPSS versi 22. Dari 19 butir pertanyaan yang di uji di peroleh hasil semua pertanyaan di nyatakan "valid" kerena nilai r-hitung yang di hasilkan lebih dari nilai r-tabel sedangkan yang tidak valid adalah 3 instrumen yang tidak valid karena nilah r-hitung yang di hasilkan kurang dari nilah r-tabel.

Kesimpulan pada uji validitas pertanyaan variabel Kualitas pelayanan $(X)$ adalah dari 22 butir pertanyaan yang diuji diperoleh hasil semua instrumen dinyatakan "Valid" dan tidak valid. Yang valid karena nilai r-hitung yang dihasilkan lebih dari nilai r-tabel. Sedangkan yang tidak valid karena nilai r-hitung lebih kecil dari nilai r-tabel sehingga semua pertanyaan dapat digunakan dalam uji validitas.

Tabel 2. Hasil Uji Validitas Kepuasan Nasabah

\begin{tabular}{|c|c|r|r|c|}
\hline \multirow{2}{*}{ Variabel } & $\begin{array}{c}\text { Label } \\
\text { Pernyataan }\end{array}$ & \multicolumn{1}{c|}{$\mathbf{r}$-hitung } & $\mathbf{r}$-tabel & ket \\
\hline \multirow{5}{*}{$\begin{array}{c}\text { Kepuasan Nasabah } \\
\text { (Y) }\end{array}$} & 1 & 0.444 & 0,2564 & Valid \\
\cline { 2 - 5 } & 2 & 0.347 & 0,2564 & Valid \\
\cline { 2 - 5 } & 3 & 0.549 & 0,2564 & Valid \\
\cline { 2 - 5 } & 4 & 0.644 & 0,2564 & Valid \\
\cline { 2 - 5 } & 5 & 0.588 & 0,2564 & Valid \\
\cline { 2 - 5 } & 6 & 0.245 & 0,2564 & Tidak Valid \\
\cline { 2 - 5 } & 7 & 0.478 & 0,2564 & Valid \\
\cline { 2 - 5 } & 8 & 0.414 & 0,2564 & Valid \\
\cline { 2 - 5 } & 9 & 0.401 & 0,2564 & Valid \\
\cline { 2 - 5 } & 10 & 0.473 & 0,2564 & Valid \\
\hline
\end{tabular}

Sumber: Data di olah 2021 
Berdasarkan tabel di atas, dari 10 butir pertanyaan terdapat 1 butir pertanyaan yang tidak valid. Hal ini dapat dilihat dari nilai rhitung< 0,245 lebih kecil dari nilai nilai r-tabel 0,2564 lebih besar. Dari tabel diatas di ketahui bahwa uji validitas terhadap kepuasan Nasabah (Y) nilai nilai r-tabel, kemudian dengan menggunakan dasar pengambilan keputusan pada uji validitas, maka didapatkan hasil yaitu : Dari 10 butir pertanyaan yang diuji diperoleh hasil 9 pertanyaan dinyatakan "Valid" karena nilai r-hitung yang dihasilkan lebih dari nilai r-tabel. Sedangkan 1 butir pertanyaan yang tidak valid.

Kesimpulan pada uji validitas instrumen variabel Kepuasan Nasabah $(Y)$ adalah 10 butir pertanyaan yang diuji dan diperoleh hasil 9 pertanyaan dinyatakan "Valid" karena nilai r-hitung yang dihasilkan lebih dari nilai r-tabel. Sedangkan 1 butir pertanyaan yang tidak valid Sehingga semua pertanyaan yang dapat digunakan dalam uji validitas dinyatakan valid adalah 9 butir pertanyaan $\mathrm{k}$ variabel $(\mathrm{Y})$.

Tabel 3. Hasil Uji Validitas Loyalitas Nasabah

\begin{tabular}{|l|c|c|c|c|}
\hline & Lael Pernyataan & $\mathbf{r}$-hitung & $\mathbf{r}$-tabel & ket \\
\hline \multirow{4}{*}{ Loyalitas Nasabah (Z) } & 1 & 0.311 & 0,2564 & Valid \\
\cline { 2 - 5 } & 2 & 0.454 & 0,2564 & Valid \\
\cline { 2 - 5 } & 3 & 0.281 & 0,2564 & Valid \\
\cline { 2 - 5 } & 4 & 0.489 & 0,2564 & Valid \\
\cline { 2 - 5 } & 5 & 0.388 & 0,2564 & Valid \\
\cline { 2 - 5 } & 6 & 0.345 & 0,2564 & Valid \\
\cline { 2 - 5 } & 7 & 0.452 & 0,2564 & Valid \\
\hline
\end{tabular}

Sumber : Data diolah 2021

Dari tabel diatas diketahui bahwa uji validitas terhadap variabel Loyalitas Nasabah (Z) sebanyak 7 butir pertanyaan. Penulis membandingkan hasil nilai r-hitung dengan nilai r-tabel, kemudian dengan menggunakan dasar pengambilan keputusan pada uji validitas, maka didapatkan hasil yaitu : Dari 7 instrumen yang diuji dan diperoleh hasil 7 butir pertanyaan dinyatakan "Valid" karena nilai r-hitung yang dihasilkan lebih dari nilai r-tabel.

Kesimpulan pada uji validitas instrumen variabel Loyalitas Nasabah (Z) adalah dari 7 butir pertanyaan yang diuji dan diperoleh hasil dinyatakan "Valid" karena nilai r-hitung yang dihasilkan lebih dari nilai r-tabel. Sehingga semua pertanyaan dapat digunakan dalam uji validitas dinyatakan valid.

\section{Uji Reliabilitas}

Pengujian reliabilitas dimaksudkan untuk mengetahui tingkat konsistensi jawaban kuesioner, sehingga mampu menunjukkan keandalan sebuah alat ukur. Dalam pengujian ini dilakukan dengan Uji Cronbach's Alpha. Nilai Cronbach's Alpha $>762$ maka pertanyaan tersebut dapat dinyatakan reliabel. Hasil uji reliabilitas dapat ditunjukkan pada tabel berikut: Berikut adalah hasil uji reliabilitas dari variabel kualitas pelayanan terhadap kepuasan nasabah dan loyalitas nasabah dengan 60 responden para uji.

a) Variabel Kualitas Pelayanan

Tabel 4. Hasil Uji Reliabilitas Kualitas Pelayanan

\begin{tabular}{|l|l|l|l|}
\hline Variabel & Cronbach,s Alpaha & $\mathrm{N}$ of Item & Keterangan \\
\hline Kualitas pelayanan & 762 & 10 & Reliabel \\
\hline
\end{tabular}

Sumber: Data diolah 2021

Dari tabel diatas menunjukkan nilai Cronbach's Alpha atas variabel kualitas pelayanan sebesar 762. Dengan demikian, dapat disimpulkan bahwa pertanyaan dalam kuisioner ini reliabel karena mempunyai nilai Cronbach's Alpha lebih besar dari 0,05.

b) Variabel Kepuasan Nasabah

Tabel 5. Hasil Uji Reliabilitas Kepuasan Nasabah 


\begin{tabular}{|l|l|l|l|}
\hline Variabel & Cronbach,s Alpaha & $\mathrm{N}$ of Item & Keterangan \\
\hline Kepuasan Nasabah & 693 & 11 & Reliabel \\
\hline
\end{tabular}

Dari tabel 4.5 menunjukkan nilai Cronbach Alpha atas variabel kepuasan nasabah sebesar 693. Dengan demikian, dapat disimpulkan bahwa pertanyaan dalam kuisioner ini reliabel karena mempunyai nilai Cronbach Alpha lebih besar dari 0,05 .

Tabel 6. Hasil Uji Reliabilitas Loyalitas Nasabah

\begin{tabular}{|l|l|l|l|}
\hline Variabel & Cronbach,s Alpaha & N of Item & Keterangan \\
\hline Kepuasan Nasabah & 676 & 8 & Reliabel \\
\hline Sumber: Data diolah 2021
\end{tabular}

Dari tabel diatas menunjukkan nilai Cronbach's Alpha atas variabel loyalitas nasabah sebesar 676. Dengan demikian, dapat disimpulkan bahwa pertanyaan dalam kuisioner ini reliabel karena mempunyai nilai Cronbach's Alpha lebih besar dari 0,05.

\section{B. Analisa Deskriptif}

Analisis deskriptif dalam penelitian ini menjelaskan profil PT Bank Papua KCP Waena berdasarkan karakteristik responden. Karakteristik responden yang dianalisis dalam penelitian ini meliputi data jenis kelamin, umur, dan tingkat pendidikan.

\section{Kualitas Layanan}

Tabel 7. Frekuensi Tanggapan Variabel Kualitas Pelayanan

\begin{tabular}{|c|c|c|c|c|c|c|c|c|c|c|c|c|}
\hline \multirow{2}{*}{ Item } & \multicolumn{2}{|c|}{ STS } & \multicolumn{2}{|c|}{ TS } & \multicolumn{2}{|c|}{ RR/N } & \multicolumn{2}{|c|}{ S } & \multicolumn{2}{|c|}{ SS } & \multirow{2}{*}{$\frac{\text { Jumlah }}{\mathrm{F}}$} & \multirow[t]{2}{*}{$\%$} \\
\hline & $F$ & $\%$ & $F$ & $\%$ & $F$ & $\%$ & $F$ & $\%$ & $F$ & $\%$ & & \\
\hline P.1 & 0 & - & 0 & - & 14 & 14.0 & 30 & 30.0 & 16 & 16.0 & 60 & 100 \\
\hline P.2 & 0 & - & 0 & - & 3 & 0,3 & 22 & 0,22 & 35 & 0,35 & 60 & 100 \\
\hline P.3 & 0 & - & 0 & - & 5 & 0,5 & 11 & 0,11 & 44 & 0,44 & 60 & 100 \\
\hline P.4 & 0 & - & 0 & - & 10 & 0,10 & 31 & 0,31 & 19 & 0,19 & 60 & 100 \\
\hline P.5 & 0 & - & 0 & - & 16 & 0,16 & 25 & 0,25 & 19 & 0,19 & 60 & 100 \\
\hline P.6 & 0 & - & 0 & - & 10 & 0,10 & 24 & 0,24 & 25 & 0,25 & 60 & 100 \\
\hline P.7 & 0 & - & 0 & - & 12 & 0,12 & 33 & 0,33 & 15 & 0,15 & 60 & 100 \\
\hline P.8 & 0 & - & 0 & & 6 & 0,6 & 25 & 0,25 & 29 & 0,29 & 60 & 100 \\
\hline P.9 & 0 & - & 0 & - & 13 & 0,13 & 14 & 0,14 & 33 & 0,33 & 60 & 100 \\
\hline P.10 & 0 & - & 0 & - & 10 & 0,10 & 30 & 0,30 & 20 & 0,20 & 60 & 100 \\
\hline P.11 & 0 & - & 0 & - & 14 & 0,14 & 27 & 0,27 & 19 & 0,19 & 60 & 100 \\
\hline P.12 & 0 & - & 0 & - & 10 & 0,10 & 29 & 0,29 & 21 & 0,21 & 60 & 100 \\
\hline P.13 & 0 & - & 0 & - & 9 & 0,9 & 33 & 0,33 & 18 & 0,18 & 60 & 100 \\
\hline P.14 & 0 & - & 0 & - & 16 & 0,16 & 24 & 0,24 & 20 & 0,20 & 60 & 100 \\
\hline P.15 & 0 & - & 0 & - & 10 & 0,10 & 22 & 0,22 & 28 & 0,28 & 60 & 100 \\
\hline P.16 & 0 & - & 0 & - & 12 & 0,12 & 33 & 0,33 & 15 & 0,15 & 60 & 100 \\
\hline P.17 & 0 & - & 0 & - & 8 & 0,8 & 33 & 0,33 & 19 & 0,19 & 60 & 100 \\
\hline P.18 & 0 & - & 1 & 0,1 & 11 & 0,11 & 28 & 0,28 & 20 & 0,20 & 60 & 100 \\
\hline P.19 & 0 & - & 0 & - & 12 & 0,12 & 28 & 0,28 & 26 & 0,26 & 60 & 100 \\
\hline P.20 & 0 & - & 0 & - & 9 & 0,9 & 35 & 0,35 & 16 & 0,16 & 60 & 100 \\
\hline P.21 & 0 & - & 0 & - & 19 & 0,19 & 24 & 0,24 & 17 & 0,17 & 60 & 100 \\
\hline P.22 & 0 & - & 0 & - & 14 & 0,14 & 36 & 0,36 & 10 & 0,10 & 60 & 100 \\
\hline
\end{tabular}

Sumber: Data diolah 2021 
Dari tabel diatas maka dapat dilihat dari tanggapan responden terhadap Pertanyaan 1 (kemudahan tempat parkir di saat pandemi covid-1 9 Bank Papua KCP Waena) responden memiliki (Sangat setujuh), 16 orang $(0,16)$,memilih setujuh sebanyak 30 orang $(0,30)$ ragu-ragu /netral sebanyak 14 orang $(0,14)$ untuk pertanyaan 2 (Bank Papua KCP Waena kerapian penampilan karyawan di saat pandemi covid-19. (Setujuh setujuh), sebanyak 35 orang $(0,35)$ memili setujuh sebanyak 22 orang $(0,22)$,memilih ragu-ragu/netral sebayak orang $3(0,3)$ Untuk pertanyaan 3 Bank Papua KCP Waena kenyamanan ruangan di saat pandemi covid-19. Responden Sangat Setujuh sebanyak 44 orang $(0,44)$ memilih setujuh sebanyak 11 orang $(0,11)$ memilih ragu-ragu/netral sebanyak 5 orang $(0,5)$. Tanggapan responden untuk pertanyaan 4 Bank Papua KCP Waena kelengkapan fasilitas fisik yang di miliki di saat pandemi covid-19. Responden sangat setujuh sebanyak 19 orang $(0,19)$ memilih setujuh sebanyak 31 orang $(0,31)$ memilih Ragu-ragu/ netral sebanyak 10 orang $(0,10)$.

Untuk pertanyaan 5 Bank Papua KCP Waena kelengkapan alat pencegahan virus corona/covid-19 di saat pandemi covid19 misalnya,masker tempat cuci tangan,anti Virus dll.Responden sangat Setuju sebanyak 19 orang $(0,19)$,memilih setujuh sebanyak 25 orang $(0,25)$, memilih ragu-ragu/netral sebanyak 16 orang $(0,16)$. Untuk pertanyaan 6 Bank Papua KCP Waena protokol kesehatan yang sudah di terapkan di saat pandemi covid-19.Responden sangat setujuh sebanyak 25 orang $(0,25)$, memilih setujuh sebanyak 24 orang) 0,24),memilih ragu-ragu/netral sebanyak 10 orang $(0,10)$. Untuk pertanyaan 7 Bank papua KCP Waena Pelayanan dari karyawan cepat di saat pandemi covid-19. Responden sangat setujuh sebanyak 15 oranga $(0,15)$,memilih setujuh sebanyak 33 orang $(0,33)$,memilih ragu-ragu/netral sebayak 12 orang $(0,12)$. Untuk pertanyaan 8 Bank Papua KCP Waena karyawan siap menolong memberikan pelayanan terhadap nasabah di saat pandemi covid-19. Responden sangat setujuh sebanyak 29 orang $(0,29)$,memilih setujuh sebanyak 25 orang $(0,25)$, memilih ragu-ragu/netral sebanyak 6 orang $(0,6)$. untuk pertanyaan 9 Bank Papua KCP Waena kondisi antrian dengan baik di masa pandemi covid-19. Responden sangat setujuh sebanyak 33 orang $(0,33)$, memilih setujuh sebanyak 14 orang $(0,14)$, memilih ragu-ragu/netral sebanyak 13 orang $(0,13)$.

Untuk pertanyaan 10 Bank Papua KCP Waena kemampuan untuk melakukan pelayanan terhadap nasabah di saat pandemi covid-19. Responden sangat setujuh 20 orang $(0,20)$, memilih setujuh sebanyak 30 orang $(0,30)$, memilih raguragu/netral sebanyak 10 orang $(0,10)$. Kemudian untuk pertanyaan 11 Bank Papua KCP Waena nasabah mampu untuk mencegah dari virus corona/pandemi covid-19. Responden sangat setujuh sebanyak 19 orang $(0,19)$, memilih setujuh sebnyak 27 orang $(0,27)$,memilih ragu-ragu/sebanyak 14 orang $(0,14)$. Untuk pertanyaan 12 Bank Papua KCP Waena kemampuan karyawan cepat tanggap dalam mengatasi keluhan nasabah di saat pandemi covid-19. Responden sangat Setujuh sebanyak 21 orang $(0,21)$, memilih setujuh sebanyak 29 orang $(0,29)$, memilih ragu-ragu/netral sebanyak 10 orang $(0,10)$. Untuk pertanyaan 13 Bank Papua KCP Waena karyawan memenuhui permintaan nasabah di saat pandemi Covid-19. Responden sangat setujuh sebanyak 18 orang $(0,18)$,memilih setujuh sebanyak 33 orang $(0,33)$,memilih ragu-ragu/netral sebanyak 9 orang $(0,9)$.

Untuk pertanyaan 14 karyawan Bank Papua KCP Waena memberikan informasi yang jelas dan mudah di mengerti nasabah di masa pandemi Covid-19. Responden Sangat Setujuh sebanyak 20 orang $(0,20)$,memilih setujuh sebanyak 24 orang $(0,24)$,memilih ragu-ragu/netral sebanyak 16 orang $(0,16)$,memilih ragu-ragu/netral sebanyak 16 orang $(0,16)$. Untuk pertanyaan 15 Bank Papua KCP Waena nasabah mampu melakukan transaksi di saat pandemi Covid-19. Responden Sangat setujuh sebanyak 28 orang $(0,28)$, memilih setujuh sebanyak 22 orang $(0,22)$,memilih ragu-ragu/netral sebanyak 10 orang $(0,10)$. Untuk pertanyaan 16 Bank Papua KCP Waena ketelitian karyawan dalam mencatat setiap transaksi nasabah yang di inginkan di saat pandemi Covid-19. Responden sangat setujuh 15 orang $(0,15)$,memilih setujuh sebanyak 33 orang $(0,33)$,memilih ragu-ragu/netral sebanyak 12 orang $(0,12)$. Untuk pertanyaan 17 Bank Papua KCP Waena melakukan transaksi sangat mudah di saat pandemi Covid-19. Responden sangat Setujuh sebanyak 19 orang $(0,19)$,memilih setujuh sebanyak 33 orang $(0,33)$, memilih ragu-ragu/netral sebanyak 8 orang $(0,8)$. Untuk pertanyaan 18 Bank Papua KCP Waena kepahaman karyawan terhadap nasabah di saat pandemi Covid-19. Responden sangat Setujuh sebanyak 20 orang $(0,20)$,memilih setujuh sebanyak 28 orang $(0,28)$,memilih ragu-ragu/netral sebanyak 11 orang $(0,11)$,memilih tidak setujuh 1 orang $(0,1)$. Untuk pertanyaan 19 Bank Papua KCP Waena kesungguhan karyawan memperhatikan kepentingan nasabah disaat pandemi Covid19. Responden Sangat Setujuh sebanyak 26 orang $(0,26)$, memilih setujuh sebanyak 28 orang $(0,28)$,memilh ragu-ragu/netral sebanyak 12 orang $(0,12)$. 
Untuk pertanyaan 20 karyawan Bank Papua KCP Waena mendengarkan ketiga nasabah memintah pelayanan di masa pandemi Covid-19.Responden sangat setujuh sebanyak 16 orang $(0,16$ (,memilih setujuh sebanyak 35 orang $(0,35)$, memilih ragu-ragu/netral sebanyak 9 orang $(0,9)$. Untuk pertanyaan 21 Bank Papua KCP Waena perlakuan karyawan pada seluruh nasabah sama disaa pandemi Covid-19. Responden sangat Setujuh sebanyak 17 orang (0,17),memilih setujuh sebanyak 24 orang $(0,24)$,memilih ragu-ragu/netral sebanyak 19 orang $(0,19)$. Dan untuk pertanyaan 22 Bank Papua KCP Waena karyawan memberikan perhatian yang lebih kepada nasabah di saat Pandemi Covid-19. Responden Sangat Setujuh sebanyak 10 orang $(0,10)$, memilih setujuh sebanyak 36 orang $(0,36)$, memilih ragu-ragu/netral sebanyak 14 orang $(0,14)$.

\section{Kepuasan Nasabah}

Tabel 8. Frekuensi Tanggapan Variabel Kepuasan Nasabah

\begin{tabular}{|c|c|c|c|c|c|c|c|c|c|c|c|c|}
\hline \multirow{2}{*}{ Item } & \multicolumn{2}{|c|}{ STS } & \multicolumn{2}{|c|}{ TS } & \multicolumn{2}{|c|}{ RR/N } & \multicolumn{2}{|c|}{$S$} & \multicolumn{2}{|c|}{ SS } & \multirow{2}{*}{$\begin{array}{c}\text { Jumlah } \\
\mathrm{F}\end{array}$} & \multirow[t]{2}{*}{$\%$} \\
\hline & $F$ & $\%$ & $F$ & $\%$ & $F$ & $\%$ & $F$ & $\%$ & $F$ & $\%$ & & \\
\hline P.1 & 0 & - & 0 & - & 7 & 0,7 & 25 & 0,25 & 28 & 0,28 & 60 & 100 \\
\hline P.2 & 0 & - & 0 & - & 5 & 0,5 & 18 & 0,18 & 37 & 0,37 & 60 & 100 \\
\hline P.3 & 0 & - & 0 & - & 9 & 0,9 & 33 & 0,33 & 18 & 0,18 & 60 & 100 \\
\hline P.4 & 0 & - & 0 & - & 8 & 0,8 & 34 & 0,34 & 18 & 0,18 & 60 & 100 \\
\hline P.5 & 0 & - & 0 & - & 7 & 7.0 & 35 & 0,35 & 18 & 0,18 & 60 & 100 \\
\hline P.6 & 0 & - & 0 & - & 13 & 0,13 & 22 & 0,22 & 25 & 0,25 & 60 & 100 \\
\hline P.7 & 0 & - & 0 & - & 10 & 0,10 & 35 & 0,35 & 15 & 0,15 & 60 & 100 \\
\hline P.8 & 0 & - & 0 & - & 11 & 0,11 & 32 & 0,32 & 17 & 0,17 & 60 & 100 \\
\hline P.9 & 0 & - & 0 & - & 3 & 0,3 & 35 & 0,35 & 22 & 0,22 & 60 & 100 \\
\hline P.10 & 0 & - & 0 & - & 22 & 0,22 & 25 & 0,25 & 13 & 0,13 & 60 & 100 \\
\hline
\end{tabular}

Sumber: Data diolah 2021

Dari tabel diatas maka dapat dilihat dari tanggapan responden terhadap Pertanyaan 1 Saya merasa puas dengan sistem pelayanan yang di berikan oleh Bank Papua KCP Waena di saat pandemi Covid-19. Responden Sangat Setujuh sebanyak 28 orang $(0,28)$,memilih setujuh sebanyak 25 orang $(0,25)$,memilh ragu-ragu/netral sebanyak 7 orang $(0,7)$. Untuk pertanyaan 2 saya merasa puas dengan mengikuti protokol kesehatan yang di terapkan di Bank Papua KCP Waena di saat pandemi Covid19. Responden sangat setujuh sebanyak 37 orang $(0,37)$,memilih setujuh sebanyak 18 orang $(0,18)$,memilih ragu-ragu/netral sebanyak 7 orang $(0,7)$. Untuk pertanyaan 3 saya merasa puas dengan fasilitas yang ada di Bank Papua KCP Waena. Responden Sangat setujuh 18 orang $(0,18)$,memilih setujuh sebanyak 33 orang $(0,33)$,memilih ragu-ragu/netral sebanyak 9 orang $(0,9)$. Untuk pertanyaan 4 Saya merasa puas dengan pelayanan yang di berikan dari karyawan Bank Papua KCP Waena disaat pandemi Covid-19.Responden sangat setujuh sebanyak 18 orang $(0,18)$,memilih setujuh sebanyak 34 orang $(0,34)$,memilih ragu-ragu/netral sebanyak 8 orang $(0,8)$. Untuk pertanyaan 5 saya merasa puas dengan karyawan Ban $\mathrm{k}$ Papua KCP Waena sangat Sopan di saat pandemi Covid-19.Responden Sangat Setujuh sebanyak 18 orang $(0,18)$,memili setujuh sebanyak 35 orang $(0,35)$, memilih ragu-ragu/netral sebanyak 7 orang $(0,7)$.

Dan untuk pertanyaan 6 Saya merasa puas karyawan Bank Papua KCP Waena sangat siap untuk melayani seluruh nasabah di saat pandemi Covid-19.Responden sangat Setujuh sebanyak 25 orang $(0,25)$,memilih setujuh sebanyak 22 orang $(0,22)$,memilih ragu-ragu/netral sebanyak 13 orang $(0,13)$. Untuk pertanyaan 7 saya merasa puas dengan transaksi Bank Papua KCP Waena di saat pandemi Covid-19. Responden sangat setujuh sebanyak 15 orang $(0,15)$,memilih setujuh sebanyak 35 orang $(0,35)$, memilih ragu-ragu/netral sebanyak 10 orang $(0,10)$. Untuk pertanyaan 8 saya merasa puas deangan penangganan pembukuan rekening disaat pandemi Covid-19. Responden sangat Setujuh sebanyak 17 orang $(0,17)$,memilih setujuh sebanyak 32 orang $(0,32)$,memilih ragu-ragu/netral sebanyak 11 orang $(0,11)$. Untuk pertanyaan 9 saya merasa puas dengan penanganan dalam transaksi teller di saat pandemi Covid-19.Responden sangat setujuh sebanyak 22 orang $(0,22)$, memilih setujuh sebanyak 35 orang $(0,35)$,memilih ragu-ragu/netral sebayak 3 orang $(0,3)$. Untuk pertanyaan 10 berapa lama dalam pananganan kepuasan nasabah (IT) disaat pandemi covid-19.Responden sangat Setujuh sebanyak 13 oranG $(0,13)$, memilih setujuh sebanyak 25 orang $(0,25)$, memilih ragu-ragu/netral sebanyak 22 orang $(0,22)$. 


\section{Loyalitas Nasabah}

Tabel 9. Frekuensi Tanggapan Variabel Loyalitas Nasabah

\begin{tabular}{|c|c|c|c|c|c|c|c|c|c|c|c|c|}
\hline \multirow{2}{*}{ Item } & \multicolumn{2}{|c|}{ STS } & \multicolumn{2}{|c|}{ TS } & \multicolumn{2}{|c|}{ RR/N } & \multicolumn{2}{|c|}{ S } & \multicolumn{2}{|c|}{ SS } & Jumlah & \multirow{2}{*}{$\%$} \\
\cline { 2 - 14 } & $\mathbf{F}$ & $\%$ & $\mathbf{F}$ & $\%$ & $\mathbf{F}$ & $\%$ & $\mathbf{F}$ & $\%$ & $\mathbf{F}$ & $\%$ & $\mathbf{F}$ & \\
\hline P.1 & 0 & - & 0 & - & 14 & 0,14 & 23 & 0,23 & 23 & 0,23 & 60 & 100 \\
\hline P.2 & 0 & - & 0 & - & 6 & 0,6 & 34 & 0,34 & 20 & 0,20 & 60 & 100 \\
\hline P.3 & 0 & - & 0 & - & 17 & 0,17 & 33 & 0,33 & 10 & 0,10 & 60 & 100 \\
\hline P.4 & 0 & - & 0 & - & 8 & 0,8 & 34 & 0,34 & 18 & 0,18 & 60 & 100 \\
\hline P.5 & 0 & - & 0 & - & 8 & 0,8 & 23 & 0,23 & 29 & 0,29 & 60 & 100 \\
\hline P.6 & 0 & - & 0 & - & 23 & 0,23 & 29 & 0,29 & 8 & 0,8 & 60 & 100 \\
\hline P.7 & 0 & - & 0 & - & 2 & 0,2 & 21 & 0,21 & 37 & 0,37 & 60 & 100 \\
\hline
\end{tabular}

Sumber: Data diolah 2021

Dari tabel diatas maka dapat dilihat dari tanggapan responden terhadap Pertanyaan 1 menginformasikan kebaikan Bank Papua KCP Waena kepada orang lain di saat pandemi Covid-19.Responden Sangat Setujuh sebanyak 23 orang $(0,23)$,memilih setujuh sebanyak 23 orang $(0,23)$,memilih ragu-ragu/netral sebanyak 14 orang $(0,14)$. Untuk pertanyaan 2 memberi saran kepada Bank Papua KCP Waena demi kemajuan di saat pandemi Covid-19.Responden sangat setujuh sebnayak 20 orang $(0,20)$,memilih setujuh sebanyak 34 orang $(0,34)$,memilih ragu-ragu/netral sebanyak 6 orang $(0,6)$. Untuk pertanyaan 3 nasabah Bank Papua KCP Waena tidak ingin pindah ke Bank lain di saat pandemi Covid-19.Responden sangat Setujuh sebanyak 10 orang $(0,10)$,memilih setujuh sebanyak 33 orang $(0,33)$,memilih ragu-ragu/netral sebanyak 17 orang $(0,17)$. Untuk pertanyaan 4 Bank Papua KCP Waena merupakan Bank terbaik di saat pandemi covid-19.Responden sangat Setujuh sebanyak 18 orang $(0,18)$, memilih setujuh sebanyak 34 orang $(0,34)$, memilih ragu-ragu/netral sebanyak 8 orang $(0,8)$. Untuk pertanyaan 5 Bank Papua KCP Waena merupakan Bank terpecaya di saat pandemi Covid-19. Responden sangat Setujuh sebanyak 29 orang $(0,29)$,memilih setujuh sebanyak 23 orang $(0,23)$, memilih ragu-ragu/netral sebanyak 8 orang $(0,8)$. untuk pertanyaan 6 Bank Papua KCP Waena merekomendasikan kepada orang lain untuk menggunakan tabungan Bank Papua KCP Waena di saat pandemi Covid-19.Responden sangat Setujuh sebanyak 8 orang (0,8),memilih setujuh sebanyak 29 orang $(0,23)$,memilih ragu-ragu/netral sebanyak 23 orang $(0,23)$. Untuk pertanyaan 7 Bank Papua KCP Waena jam kerja karyawan di saat pandemi Covid-19. Responden sangat Setujuh sebanyak 37 orang $(0,37)$,memilih setujuh sebanyak 21 orang $(0,21)$, memilih ragu-ragu/netral sebanyak 2 orang $(0,2)$.

\section{Uji Asumsi Klasik}

\section{Uji Normalitas}

Uji normalitas data digunakan untuk melihat apakah dalam model regresi variabel terikat (dependent) dan variabel bebas (independent) memiliki distribusi normal atau tidak. Uji normalitas data dalam penelitian ini yaitu dengan analisis grafik dan analisis statistik.

a) Uji Normalitas dengan P-Plot dan Histogram

Dengan melihat grafik histogram dan P-Plot yang dihasilkan dari program SPSS maka penulis dapat mengetahui apakah data yang digunakan berdistribusi normal atau tidak. Dasar pengambilan keputusan Uji Normalitas dengan Grafik Histogram dan P-Plot adalah sebagai berikut :

1) Data berdistribusi normal, jika data menyebar disekitar garis diagonal dan mengikuti garis arah garis diagonal atau grafik histogramnya.

2) Sebaliknya data dikatakan tidak berdistribusi normal, jika data menyebar jauh dari arah garis atau tidak mengikuti diagonal atau grafik histogramnya.

Gambar 2.

P-plot dan Histogram 

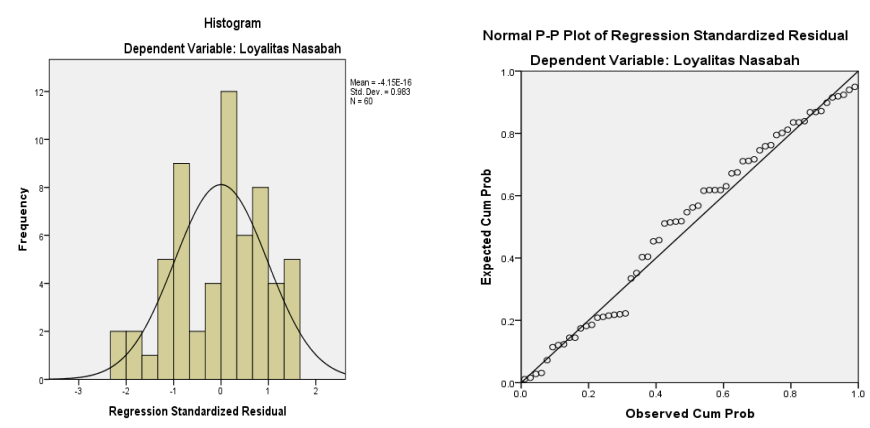

Sumber: Data diolah 2021

Berdasarkan gambar 2. uji normalitas tampilan output chart diatas dapat terlihat pada grafik histogram maupun grafik plot. Dimana grafik histogram memberikan pola distribusi yang melenceng ke kanan yang artinya adalah data berdistribusi normal.Kemudian pada grafik P-Plot terlihat titik-titik mengikuti garis diagonal sehingga dapat disimpulkan bahwa model data berdistribusi normal dan berdistribusi tidak normal karena garis p-plot titik-titik mengikuti garis diagonal melencer dari titik titik garis bola.

\section{Uji Multikolimeantas}

Uji Multikolinearitas bertujuan untuk menguji apakah model regresi ditemukan adanya korelasi antar variabel bebas (independent). Model regresi yang baik seharusnya tidak terjadi korelasi diantara variabel bebas (tidak terjadi multikolinearitas). Jika variabel bebas saling berkorelasi, maka variabel-variabel ini tidak ortogonal atau adalah variabel bebas yang nilai korelasi antar sesama variabel sama dengan nol.

Tabel 10. Hasil Uji Multikolinearitas Coefficientsa Coefficientsa

\begin{tabular}{|c|c|c|c|c|c|c|c|}
\hline \multirow[b]{2}{*}{ Model } & \multicolumn{2}{|c|}{$\begin{array}{c}\text { Unstandardized } \\
\text { Coefficients }\end{array}$} & \multirow{2}{*}{$\begin{array}{c}\begin{array}{c}\text { Standardized } \\
\text { Coefficients }\end{array} \\
\text { Beta }\end{array}$} & \multirow[b]{2}{*}{$\mathrm{t}$} & \multirow[b]{2}{*}{ Sig. } & \multicolumn{2}{|c|}{ Collinearity Statistics } \\
\hline & B & $\begin{array}{l}\text { Std. } \\
\text { Error }\end{array}$ & & & & Tolerance & VIF \\
\hline (Constant) & -6.562 & 7.523 & & -.872 & .387 & & \\
\hline Kualitas Pelayanan & .211 & .087 & .282 & 2.441 & .018 & .860 & 1.163 \\
\hline Kepuasan Nasabah & .388 & .107 & .419 & 3.622 & .001 & .860 & 1.163 \\
\hline
\end{tabular}

a. Dependent Variable: Loyalitas Nasabah

Berdasarkan output diatas diketahui bahwa :

a) Nilai Tolerance yang dihasilkan pada Kualitas Layanan (X) dan kepuasan Nasabah ( $Y$ ) yakni 0.860 lebih besar dari 0,10. Kemudian Nilai VIF yang dihasilkan pada Kualitas Layanan (X) dan Loyalitas Nasabah (Z) yakni 1,163 lebih kecil dari 10,0. Sehingga dapat disimpulkan tidak terjadi multikolinearitas.

b) Nilai Tolerance yang dihasilkan pada Kepuasan Nasabah (X) dan Loyalitas Nasabah (Z) yakni 0.860 lebih besar dari 0,10 . Kemudian Nilai VIF yang dihasilkan pada Kepuasan Nasabah (Y) dan Loyalitas Nasabah (Z) yakni 1,163 lebih kecil dari 10,0. Sehingga dapat disimpulkan tidak terjadi multikolinearitas.

\section{Uji Heterokedatisitas}

Hasil uji heteroskedastisitas dapat dilihat pada grafik Scatterplot dari hasil output SPSS versi 22 :

Dasar Pengambilan Keputusan berdasarkan grafik Scatterplot : 
a) Jika terdapat pola tertentu pada Grafik Scatterplot SPSS, seperti titik -titik yang membentuk pola yang teratur (bergelombang, menyebar kemudian menyempit). Maka dapat disimpulkan bahwa telah terjadi heteroskedastisitas.

b) Sebaliknya, jika tidak ada pola yang jelas, serta titik-titik menyebar, maka indikasinya adalah tidak terjadi heteroskedastisitas.

\section{Gambar 3. Hasil Uji Heteroskedastisitas}

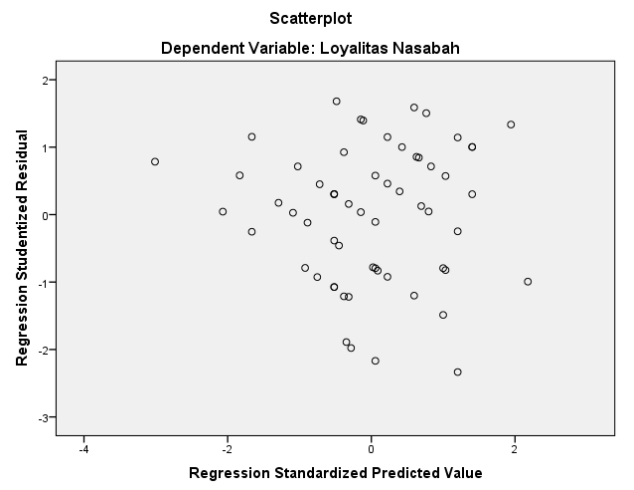

Setelah melihat hasil output diatas dapat dijelaskan bahwa titik-titik menyebar, Tidak ada pola yang jelas, maka indikasinya adalah tidak terjadi heteroskedastisitas. 


\section{Analisis Regresi Linier Berganda}

Metode Analisis dalam penelitian ini digunakan untuk mengukur hubungan antara variabel independen Kualitas Layanan

(X) dan Kepuasan Nasabah (Y) dengan variabel dependen Loyalitas Nasabah (Z). Hubungan antara variabel tersebut diwujudkan dalam suatu model matematis. Rumus regresi linier Berganda sebagai berikut :

$$
\begin{aligned}
& Y=a+b 1 X 1+b 2 X 2+e \\
& \text { Keterangan: } \\
& Y=\text { Kepusan Nasabah } \\
& a=\text { Konstanta } \\
& b 1,2,=\text { Koefisien regresi } \\
& X 1,2=\text { Kualitas Layanan dan Loyalitas Nasabah }
\end{aligned}
$$

\begin{tabular}{|c|c|c|c|c|c|c|}
\hline \multirow[b]{2}{*}{ Mode } & & \multicolumn{2}{|c|}{ Unstandardized Coefficients } & $\begin{array}{c}\text { Standardized } \\
\text { Coefficients }\end{array}$ & \multirow[b]{2}{*}{$t$} & \multirow[b]{2}{*}{ Sig. } \\
\hline & & $\mathrm{B}$ & Std. Error & Beta & & \\
\hline \multirow[t]{3}{*}{1} & (Constant) & -6.562 & 7.523 & & -.872 & .387 \\
\hline & Kualitas Pelayanan & .211 & .087 & .282 & 2.441 & .018 \\
\hline & Kepuasan Nasabah & .388 & .107 & .419 & 3.622 & .001 \\
\hline
\end{tabular}

Tabel 11. Hasil Uji Analisis Regresi Linier Berganda

\section{Coefficients}

a. Dependent Variable: Loyalitas Nasabah

Untuk menetapkan rumusan persamaan regresi linier berganda pengaruh kualitas pelayanan terhadap kepuasan nasabah dan Loyalitas Nasabah pada Bank Papua KCP Waena perlu dilakukan analisis koefisien regresi berganda. Dengan menggunakan fasilitas program SPSS 22, hasilnya adalah sebagai berikut : Konstanta sebesar -,6.562, Kualitas Layanan sebesar 0,211, sedangkan Kepuasan Nasabah sebesar 0,388.

$Y=-, 6.562+0,211+0,388+e$

Intersep dari persamaan regresi tersebut adalah sebagai berikut : Konstanta/Intersep nilainya sebesar -,6.562 secara matematis menyatakan bahwa jika nilai Kualitas Layanan dan Kepuasan Nasabah sama dengan nol maka nilai Loyalitas Nasabah adalah -,6.562. Dalam kata lain bahwa nilai Loyalitas Nasabah tanpa Kualitas Layanan dan Kepuasan Nasabah adalah,- 6.562 .

Koefisien regresi Kualitas Layanan nilainya 0,211 artinya jika pelaksanaan Kualitas Layanans skornya turun 1 (satu) satuan maka Loyalitas Nasabah akan turun 0,6.562 satuan. Koefisien regresi Kepuasan Nasabah nilainya 0,388 artinya jika pelaksanaan Kepuasan Nasabah skornya turun 1 (satu) satuan maka Loyalitas Nasabah (Z) akan turun 0,388 satuan.

\section{Uji Hipotesis}

1. Uji t-parsial

Uji t-parsial (kualitas pelayanan terhadap kepuasan nasabah dan loyalitas nasabah).Pengujian hipotesis secara parsial bertujuan untuk mengukur besarnya pengaruh variabel eksogen secara parsial terhadap variabel endogen. Hasil hipotesis dalam pengujian ini adalah sebagai berikut :

a) Persamaan Struktural 1

Uji t-parsial (kualitas pelayanan terhadap kepuasan nasabah) 
Tabel 12. Hasil Uji t-Parsial Coefficients ${ }^{a}$

\begin{tabular}{|cl|l|l|l|l|l|}
\hline \multirow{2}{*}{ Model } & \multicolumn{2}{|c|}{ Unstandardized Coefficients } & \multicolumn{2}{|c|}{$\begin{array}{c}\text { Standardized } \\
\text { Coefficients }\end{array}$} & & \\
\cline { 3 - 5 } & & $\mathrm{B}$ & Std. Error & Beta & $\mathrm{t}$ & Sig. \\
\hline 1 & (Constant) & -6.562 & 7.523 & & -.872 & .387 \\
& Kualitas Pelayanan & .211 & .087 & .282 & 2.441 & .018 \\
& Kepuasan Nasabah & .388 & .107 & .419 & 3.622 & .001 \\
\hline
\end{tabular}

a. Dependent Variable: Loyalitas Nasabah

\section{Keterangan Hasil Uji Hipotesis (t-Parsial):}

Dari hasil output SPSS.22 diatas dapat diketahui bahwa :

a) Hipotesis Pertama : Pengaruh Kualitas Layanan terhadap kepuasan Nasabah pada Bank Papua KCP Waena.

Hasilnya adalah nilai t-hitung 2.441 lebih besar dari 1,66 artinya Kualitas Layanan X berpengaruh terhadap kepuasan Nasabah. Kemudian nilai signifikan yang dihasilkan adalah 0,018 lebih kecil dari 0,05 artinya Kualitas Layanan berpengaruh signifikan terhadap kepuasan nasabah. Kesimpulan uji hipotesis pertama adalah variabel Kualitas Layanan berpengaruh signifikan terhadap kepuasan Nasabah pada Bank Papua KCP Waena. Hal ini menunjukkan bahwa hipotesis pertama yang diajukan, diterima.

b) Hipotesis Kedua : Kualitas pelayanan terhadap loyalitas Nasabah pada Bank Papua KCP Waena di masa pandemi Covid-19.

Hasilnya adalah nilai t-hitung 3.622 lebih besar dari 1,66 artinya Kepuasan Nasabah berpengaruh terhadap Loyalitas Nasabah. Kemudian nilai signifikan yang dihasilkan adalah 0,001 lebih kecil dari 0,05 artinya Kepuasan Nasabah berpengaruh signifikan terhadap Loyalitas Nasabah. Kesimpulan uji hipotesis kedua adalah variabel Kepuasan Nasabah berpengaruh signifikan terhadap Loyalitas Nasabah pada Bank Papua KCP Waena. Hal ini menunjukkan bahwa hipotesis kedua yang diajukan, diterima.

\section{PENUTUP}

\section{A. Simpulan}

Beberapa kesimpulan dari penelitian ini dapat dijelaskan sebagai berikut:

1) Kualitas pelayanan berpengaruh positif terhadap kepuasan nasabah. Hal ini berarti bahwa semakin tinggi kualitas pelayanan akan meningkatkan kepuasan nasabah pada Bank Papua KCP Waena di masa pandemi Covid-19.

2) Kualitas layanan berpengaruh positif terhadap loyalitas nasabah. Hal ini berarti bahwa semakin tinggi kualitas pelayanan akan meningkatkan loyalitas nasabah pada Bank Papua KCP Waena di masa pandemi Covid-19.

3) Kepuasan nasabah berpengaruh positif terhadap loyalitas nasabah. Hal ini berarti bahwa semakin tinggi kepuasan nasabah akan meningkatkan loyalitas nasabah.

Kualitas pelayanan berpengaruh positif terhadap loyalitas nasabah dengan kepuasan nasabah sebagai variabel mediasi. Hal ini berarti bahwa semakin tinggi kualitas pelayanan akan meningkatkan kepuasan nasabah pada Bank Papua KCP Waena di masa pandemi Covid - 19.

B. Saran

Berdasarkan kesimpulan di atas, maka penulis memberikan saran dalam penelitian ini antara lain:

\section{Bank Papua KCP Waena}


a) Dengan adanya pandemi covid-19 maka Bank Papua KCP Waena perlu menerapkan protokol kesehatan perlu menyiapkan seperti,masker, anti virus dan tempat cuci tanggan sehingga nasabah yang tidak memakai masker bisa di berikan dari Bank Papua KCP Waena dapat memuaskan di saat pandemi covid-19.

b) Diharapakan Bank Papua KCP Waena lebih meningkatkan kualitas pelayanan terhadap nasabah untuk meningkatkan loyalitas nasabah dimasa pandemi Covid-19. Dan sikap kepercayaan diri nasabah untuk lebih meyakinkan para nasabah menggunakan buku tabungan pada Bank papua KCP Waena

\section{Peneliti Selanjutnya}

Kepada peneliti selanjutnya dapat menjadikan penelitian ini sebagai referensi atau rujukan apabila melakukan penelitian sejenis pada pengukuran kualitas pelayanan terhadap kepuasan nasabah dan loyalitas nasabah pada Bank Papua KCP Waena di masa pandemi covid-19.

\section{DAFTAR PUSTAKA}

Azidni Rofiq01, (2021). Pengaruh Kualitas Pelayanan Terhadap Loyalitas Dengan Kepercayaan Dan Kepuasan Sebagai Variabel Mediator Bank Syariah Di Ponorogo. Etihad: Journal of Islamic Banking and Finance. Vol. 1, No. 1, JanuariJuni 2021: 1-11.

Abdul Kharis P. Kamaruddin, (2020). Pengaruh Loyalitas Jasa perbankan terhadap loyalitas nasabah tabungan simpedes di bank rakyat indonesia kantor unit cabang sentani kabupaten jaypaura.

Ahmad Yasin, (2019). Faktor - Faktor Yang Memengaruhi Kinerja pegawai Bank BJB Syariah Cabang Bekasi.. Jurnal Aplikasi Manajemen dan Bisnis, Vol. 5 No. 2, Mei 2019.

Agustinus Numberi, (2018). Pengaruh kualitas pelayanan terhadap kepuasan nasabah pada PT. Bank Papua Kantor Cabang Pembantu Abepura. Penerbit: Jurusan Manajemen, Fakultas Ekonomi \& Bisnis, Universitas Cenderawasih. Volume 3, Nomor 2 Edisi Juli - Desember 2019 (Issn 2615-0425, E-Issn 2622-7142).

Biurman Sigiro, (2014). Pengaruh Nilai nasabah dan kepuasan nasabah terhadap loyalitas nasabah pada PT. Bank Papua Kantor Cabang Pembantu Abepura.

Catur Prasetio, (2017). Analisis Kualitas Pelayanan Terhadap Kepuasan Nasabah Bank Negara Indonesia (BNI) Cabang Djuanda, Bogor

Demianus Asemki, (2019). Pengaruh kualitas layanan ATM Dan Kepuasan Nasabah Terhadap Loyalitas Nasabah Pada PT. Bank Papua KCP Waena Kota Jayapura.

Dedy Ansari, (2019). Harahap, Kajian Kualitas Pelayanan dan Loyalitas Nasabah Perbankan di Indonesia.

Eko putra kusuma goo, (2019). Pengaruh Lokasi, Promosi dan kualitas pelayanan terhadap loyalitas nasabah di PT. Bank Rakyat Indonesia (Persoro) Tbk. Cabang Abepura.

Edy Yulianto, (2016). Pengaruh kualitas pelayanan terhadap kepuasan nasabah Dan dampaknya pada loyalitas nasabah. Jurnal Administrasi Bisnis (JAB)| Vol. 41 No.1 Desember 2016| administrasibisnis.studentjournal.ub.ac.id

Fitriani, (2018). Pengaruh Kualitas Pelayanan Dan Kinerja Karyawan Terhadap Kepuasan Nasabah Pada Pt Bank Rakyat Indonesia (Bri) Unit Jaro Tanjung Tabalong. JAPB : Vol. 1, No. 1, April 2018

Fransiska Magdalena Pepuho, (2016). Evaluasi Kinerja Pelayanan Bank Berbasis kualitas pelayanan.

I Wayan Gede Antok Setiawan Jodi, (2019). Pengaruh Kualitas Pelayanan Dan Kinerja Karyawan Terhadap Kepuasan Nasabah Pada Pt. Bpr Artha Adyamurthi Di Kediri Tabanan. Vol. 01, No. 02, Agustus 2018-Januari 2019 ISSN : 2620-6358.

Jaka Atmaja, (2018). Kualitas Pelayanan dan Kepuasan Nasabah Terhadap Loyalitas Pada Bank BJB 
Kasmir. Dasar-Dasar Perbankan. (Jakarta: Rajawali Pers. 2010)

Marcy Rina Rumbiak, (2020). Pengaruh Kualitas pelayanan dan prosedur kredit modal kerja terhadap kepuasan nasabah mengambil kredit mdal kerja pada PT. Bank Papua KCP Abepura.

Muhammad Setiawan, (2017).Pengaruh kualitas pelayanan terhadap kepuasan nasabah serta dampaknya terhadap loyalitas nasabah. Studi Pada Bank Syariah Mandiri Cabang Jakarta.

Natalia Ribka Lumempow, (2015). Analisis Faktor-Faktor Kualitas Pelayanan Terhadap Kepuasan Nasabah Pada Pt. Bank Mandiri Tbk Cabang Bahu Mall Manado. Jurnal EMBA 1275 Vol. 3 No. 3 Sept. 2015, Hal. 1275-1286. ISSN 230311.

Nina Indah Febriana, (2016). Analisis Kualitas Pelayanan Bank Terhadap Kepuasan Nasabah Pada Bank Muamalat Indonesia Kantor Cabang

Pembantu Tulungagung. AN-NISBAH, Vol. 03, No. 01, Oktober 2016 ж 149.

Nazarudin Aziz, (2013). Pengaruh Kualitas Pelayanan Dan Kepuasan Pelanggan Terhadap Loyalitas Nasabah Pt Bank Rakyat Indonesia Cabang Padang.

Otong Karyono1, (2016). Kepuasan Nasabah Diukur Dari Kinerja Pelayanan Dan Kinerja Karyawan. Jurnal J-Ensitec: Vol 02|No. 02, Mei 2016.

Rizka Afrisalia Nitasari, (2012). Analisis Pengaruh Motivasi Kerja Terhadap Kinerja Karyawan Dengan Kepuasan Kerja Sebagai Variabel Intervening Pada PT. Bank Central Asia Tbk. Cabang Kudus.

Roby Ben Saputra, (2015). Pengaruh kualitas pelayanan dan kepuasan nasabah terhadap loyalitas nasabah pada PT.Bank Riau Kepri Cabang Siak.Vol. Vii No. 2 Mei 2015 Jurnal tepak Manajemen Bisnis 285.

Sutikno,(2019). Pengaruh kualitas layanan terhadap kepuasan dan loyalitas nasabah TP. Bank Bukopin Tbk Cabang Yogyakarta.

Soniya Fransiska, (2019). Pengaruh Kualitas Layanan Bank Terhadap Kepuasan Nasabah.

Soumokil, M. S., \& Kamaruddin, A. K. (2021). Pengaruh Kualitas Jasa Perbankan Terhadap Loyalitas Nasabah Tabungan Simpedes di Bank Rakyat Indonesia Kantor Unit Cabang Sentani Kabupaten Jayapura. JUMABIS (Jurnal Manajemen dan Bisnis), 5(1), 37-49.

Totok Ismawanto, (2020). Pengaruh Kualitas Pelayanan Dan Kinerja Karyawan Frontliner Terhadap Kepuasan Nasabah PT Bank Rakyat Indonesia (Persero), Tbk Kantor Cabang Balikpapan Sudirman Unit Klandasan. Jurnal Bisnis \& Kewirausahaan Volume 16, Issue 1, 2020 ISSN (print). 0216-9843 ISSN (online). 2580-5614 Homepage. http://ojs. pnb. ac. id/index. php/JBK.

Wahyuningtyas. S, H. N. Utami 2018. Analisis Perbedaan Kinerja Karyawan Outsourcing Dan Karyawan Tetap (Studi Pada Karyawan Bank Bri Kantor Cabang Malang Kawi), Jurnal administrasi bisnis, Vol. 60 No. 3 www. bankPapua. co. id

Yuniper Uopmabin, (2019). Pengaruh kualitas pelayanan Dan Lokasi Terhadap KeputusanNasabah Menabung Pada PT. Bank Papua Kantor Cabang Pembantu Oksibil.

Yetiy Marice Okaka, (2019). Pengaruh Kualitas Pelayanan Terhadap keputusan Nasabah Mengambil Kredit Usaha Rakyat Pada PT. Bank Negara Indonesia Tbk KCU Jayapura.

Zainul Arifin,(2015). Pengaruh kualitas pelayanan terhadap kepuasan Nasabah dan loyalitas nasabah. Studi pada Nasabah Kredit KPR PT. Bank BTN KCP Tuban. Jurnal Administrasi Bisnis (JAB)|Vol. 24 No. 1 Juli 2015| administrasibisnis.studentjournal.ub.ac.id. 